\title{
EFFECT OF THICKNESS LAYER OF KENAF FIBRE REINFOECED FIBRE GLASS, AGAINST IMPACT OF HYBRID COMPOSITE SANDWICH WITH CORE SENGON
}

\author{
Mataram, Agung ${ }^{1 *}$, Panggar Besi, Narwi ${ }^{1}$ \\ ${ }^{1}$ Department of Mechanical Engineering, Faculty of Engineering, Universitas Sriwijaya, \\ Indralaya 30662, South Sumatera, Indonesia
}

\begin{abstract}
The purpose of this research is to know the impact strength of composite structures of sengon laut sawdust. Experimental results show that the impact toughness of sandwich composite will increase as the thickness of composite sandwich skin increases. The impact failure is due mostly to the shear failure of the core. Brittle specimen failure occurs on the sandwich composites structured with skin and core manufactured with the same thickness of $5 \mathrm{~mm}$. This brittle sandwich composite has a flat cross section on both sides of the fault. The shear failure of the cores occurs in samples with $2 \mathrm{~mm}$ thick, $3 \mathrm{~mm}, 4 \mathrm{~mm}$ thick, and $10 \mathrm{~mm}$ thick core. In some samples, the shear failure of the cores is accompanied by cracks on the core so that the sandwich composite is broken in several parts. The highest value of absorption energy and the highest impact strength is found on thick composite sandwich variation of $10 \mathrm{~mm}$ thick with $4 \mathrm{~mm}$ thickness of $2,7860 \mathrm{~J}$ and $0,01032 \mathrm{~J} / \mathrm{mm}^{2}$.
\end{abstract}

Keywords: Sengon laut sawdust, Sandwich Composite, Impact strength.

\section{INTRODUCTION}

A composite sandwich mainly has two components: skin and core. Adhesive is used to bind the skin with cores. The adhesive layer is considered as an additional component in the structure. The thickness of the adhesive layer is generally negligible as it is much smaller than the thickness of the skin or cores. A strong bond between skin and cores to prevent inter-surface failures under applied loads and to improve the composite sandwich bending properties. The properties of sandwich composites depend on the properties of the skin and cores, their relative thickness and bonding characteristics among them [1].

Maximizing stiffness per unit weight of a sandwich block with foam cores has been investigated by Gibson (2016) [2]. The optimum values of core thickness, skin thickness and core density were obtained from the analysis [2]. Measurements of stiffness per unit weight have been made on sandwiches with foamy polyurethane cores [2]. Theoretical analysis is in accordance with the experimental test results [2].
Studies on composite material which have high elasticity, compressive and tensile strength are being developed. The sisal fiber composite with urea formaldehyde matrix has the highest impact strength of $9.42 \mathrm{~kJ} / \mathrm{m}^{2}$ at $50 \%$ volume fraction [3]. The addition of fiber volume fraction will lead to increased composite impact strength [3]. The mechanical properties of particle board with a $30 \%$ urea-formaldehyde composition have the best mechanical properties [4].

Mylsamy and Rajendran (2010) [5] have examined the comparison of raw agave Americana fiber properties processed under alkaline $\mathrm{NaOH}$ treatment $5 \%$, and $10 \%$ alkaline $\mathrm{NaOH}$ treatment. The results showed that agave Americana fiber with 5\% alkali treatment had the highest tensile strength [5]. In addition, it has been investigated the effect of alkali treatment on natural fiber composite materials such as cellulose, lignin and wax [6]. Furthermore, the alkali treatment with $\mathrm{NaOH}$ in chicken feather fibers can increase the toughness and elastic modulus of the chicken feather fiber composite the epoxy matrix [6]. The composite toughness increased from $18.816 \mathrm{~N} / \mathrm{mm}^{2}$ to $24,192 \mathrm{~N} / \mathrm{mm}^{2}$.

*Corresponding author’s email: amataram@unsri.ac.id 
The composite elastic modulus increased from $1,216 \mathrm{~N} / \mathrm{mm}^{2}$ to $4,339 \mathrm{~N} / \mathrm{mm}^{2}$ [6].

In a study conducted by Zainuri (2011) [7] showed that composites are formed like sandwiches with two skins flanking the core, where the skin is made by using a hand lay up technique and based on polyester fiber reinforced plant fiber from industrial waste, such as coconut fiber. The core was made of cardboard paper and was intended to reduce the composite weight and increase the stiffness, so it is worth applying. From the results can be concluded that the average bending rigidity for $30 \mathrm{~mm}, 40 \mathrm{~mm}$, and $50 \mathrm{~mm}$ thick sandwiches was 131.9 MN.mm², 134.4 MN.mm², and 136.2 MN.mm², respectively [7].

Diharjo et al. (2008) [8] states that kenafalbazzia sandwich composites with thick variations of $5,10,15$, and $20 \mathrm{~mm}$ cores have the highest impact strength value on sandwich composites with $10 \mathrm{~mm}$ thick core. Whereas for composite sandwiches with thick skin variations have increasing impact strength value along with increasing thickness skin [8].

On the other hand, Febrianto and Diharjo (2007) [9] examines the sawdust of sengon laut urea formaldehyde and concludes that the core of sawdust of sengon laut - urea formaldehyde has the high mechanical properties on the sawdust content of $60-70 \%$ [9]. The study of sandwich composites has been done and many studies have concluded that this has many benefits and advantages if applied in the industry, especially sengon laut sawdust [9]. However, there has not specially attention to characterize sengon laut sawdust as an alternative to sandwich composite. Therefore, purpose of this study is to know the mechanical characteristics of structural sandwich composite of sengon laut sawdust. This is to know the effect of skin thickness variation composed of kenaf fiber with a core composed of sengon laut sawdust to the impact strength of the composite.

\section{METHODOLOGY}

The fabrication process of sandwich composite panels was done by combining sengon laut sawdust (core) with a composite based on kenaf fiber material (skin). The process was using a hand lay up and press mold method. It began by calculating the required amount of fiber and matrix to produce a sandwich composite panel with fiber volume fraction of $30 \%$, and a matrix volume fraction of $70 \%$ (kenaf fiber mass density is $1.4 \mathrm{~g} / \mathrm{cm}^{3}$ ). The sengon laut sawdust, after drying pressed, was sprayed using resin over its entire surface, then left until it was dried. Resin spraying over the core surface had a purpose to avoid the resin liquid being absorbed by the core during in the sandwich composite manufacturing process.

To make composite panel with volume fraction of $30 \%$ fiber. First, calculating the required fiber and matrix composition. Second, prepare the mold by coating the entire surface of the mold that will be in contact with the composite using mica. The mica was used to make the surface of the specimen formed smooth and even. To facilitate the retrieval of the composite panel after hardening, the upper surface of the mica in contact with the composite panel is smeared with releaser. Third, installation of a stopper on both ends of the mold. The stopper function for the long divider and as a composite thick binder will be made. Preparation of sandwich composite panel is done by combination method of hand lay up and press mold. The resin and hardener matrices used are unsaturated polyester yukalac ${ }^{\circledR} 157$ BQTN-EX, and MEKPO. The amount of hardener used is $1 \%$.

The sandwich panel composite printing process begins by pouring the matrix evenly in the mold and then proceeding with the laying of the kenaf fiber according to the calculation. The addition of the matrix is carried out when the fiber layer is laid down to the wetted fiber completely. The core is placed on top of kenaf fiber and smeared with a matrix of resin. After uniform then the kenaf fiber is put back on the core and rewetted with resin evenly. Then, all the material is inserted into the mold then immediately do the mold pressing process by using manual hydraulic jack. Drying process in the open space (curing) about 7-8 hours, sandwich composite panels can be removed from the mold. The sandwich composite manufacturing process is shown in Figure 1.

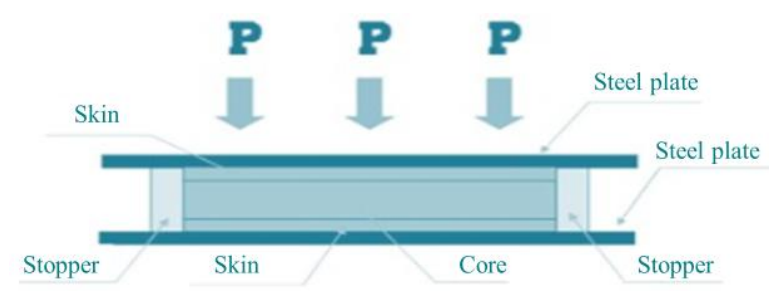

Figure 1 Schematic process of pressing the sandwich composite 


\section{RESULTS AND DISCUSSIONS}

\subsection{Results}

\subsubsection{Effect of Skin Thickness of Sandwich Composite}

To find out the strength of a sandwich composite made by sengon laut sawdust there are four samples tested with thick skin: $2 \mathrm{~mm}, 3 \mathrm{~mm}, 4 \mathrm{~mm}$ and $5 \mathrm{~mm}$ (see Figure 2).
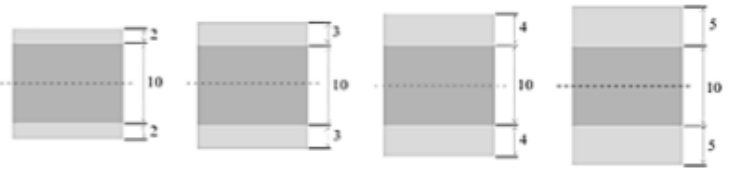

Figure 2 Sandwich composite constructed of varying skin thickness

The results of the sample strength test are summarized in Figure 3 and 4.

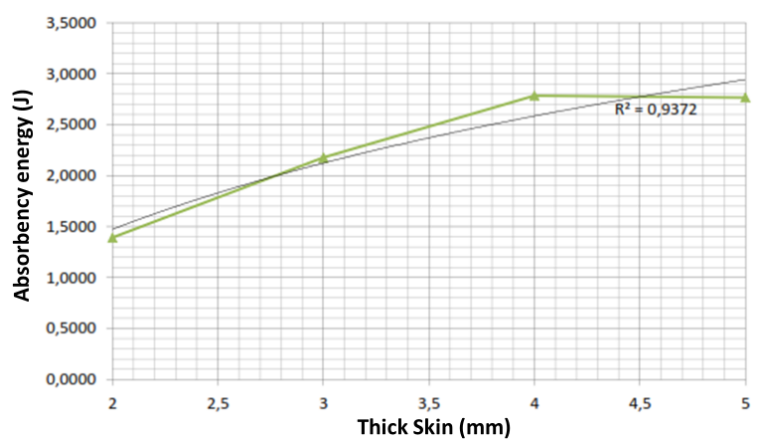

Figure 3 The relationship of the absorbed energy and thick skin

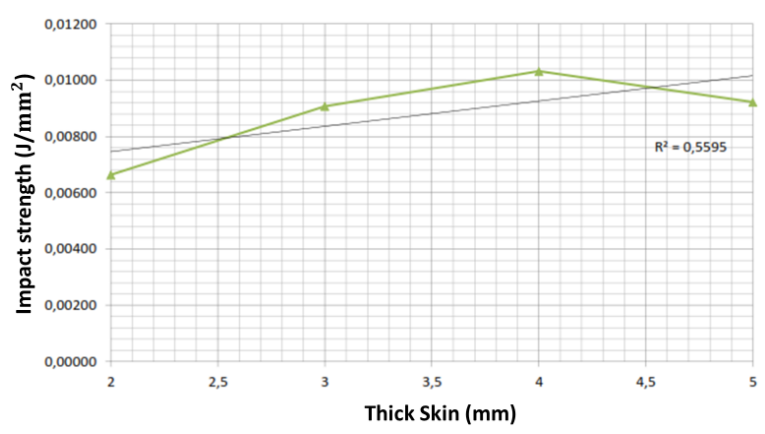

Figure 4 The relationship of the impact strength and thick skin

The composite sandwich test result with thickness of $10 \mathrm{~mm}$ cores and $2 \mathrm{~mm}$ thick skin have average value of absorbent energy and impact strength of $1,3930 \mathrm{~J}$ and $0,00663 \mathrm{~J} / \mathrm{mm}^{2}$. While the composite sandwich with thick $10 \mathrm{~mm}$ core and $3 \mathrm{~mm}$ thick skin has an absorptive energy value of 2,1778 $\mathrm{J}$ and impact energy of 0,00907 $\mathrm{J} / \mathrm{mm}^{2}$.
The value of absorption energy and impact strength of sandwich composites with $3 \mathrm{~mm}$ skin thickness increased when compared with $2 \mathrm{~mm}$ thick skin sandwich. The highest value of absorption energy and the highest impact strength is found on thick composite sandwich sample of $10 \mathrm{~mm}$ thick with $4 \mathrm{~mm}$ thickness of 2,7860 $\mathrm{J}$ and $0,01032 \mathrm{~J} / \mathrm{mm}^{2}$. While on the thickness sample of $10 \mathrm{~mm}$ core with $5 \mathrm{~mm}$ thick skin showed a decrease of value that is $2,7664 \mathrm{~J}$ for the average of absorption energy and $0,00922 \mathrm{~J} / \mathrm{mm}^{2}$ for the mean of impact strength.

From these results it can be seen that the highest impact strength value is found on the thick $10 \mathrm{~mm}$ thick core sandwich composite with $4 \mathrm{~mm}$ thick skin. From the impact test, the composite sandwiches with $10 \mathrm{~mm}$ thick core and $5 \mathrm{~mm}$ thick skin was found that the failure that occurred on the sample was broken but not on the collision area. Whereas the collision area should have the greatest burden but it turned out that the failure is not on the collision area. This indicates that the broken area experiences stress concentrations resulting in failure to occur faster before the sandwich composite reaches its maximum strength.

The increase in impact strength of the sandwich composite along with the addition of thick skin is due to the increased ability of sandwich composites to withstand the maximum load that occurs. In other words, the skin holds the load up to its maximum limit and then loads distributed cores across the entire area, skins and cores contributes optimum to increasing the impact strength of sandwich composites. Impact impact strength is also supported by the shear stress of the cores that increases along with the thickness of the composite sandwich skin.

Results of test of composite sandwich impact with thick skin variation, it was found that the research data was less regular. This is influenced by the addition of thick skin that affects the moment value of inertia and the stiffness of sandwich composites.

\subsubsection{Macroscopic Observation of Cross- Sectional Fracture on Sandwich Composite}

Different types of failure modes was observed from the impact test result, such as the shear failure in the core, single broken, and broken in some areas, etc. The observation of the impact fracture cross section was done macroscopically. 
The sample with $2 \mathrm{~mm}$ thick skin, most of the test specimens failed on the core. It was caused by sengon laut sawdust cores that were unable to withstand the shear stress acting on the core (see Figure 5-a). The sample with $3 \mathrm{~mm}$ thick skin, failure is caused by crushed cores due to impact loads that work. This failure causes the specimen to be broken into several parts and separate in the core (see Figure 5-b). The sample with $4 \mathrm{~mm}$ thick skin failure occurred in the affected area. The impact load that works causes the specimen to be broken into two parts. Some specimens have failed on the core (see Figure 5-c). The sample with $5 \mathrm{~mm}$ thick skin have good rigidity. In the collision area failure does not occur because a stress distribution occurring at a certain point which results in the maximum strength of the composite sandwich (see Figure 5-d).

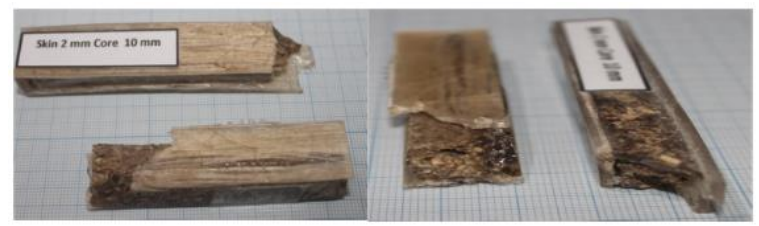

a. Sample with $2 \mathrm{~mm}$ thick skin

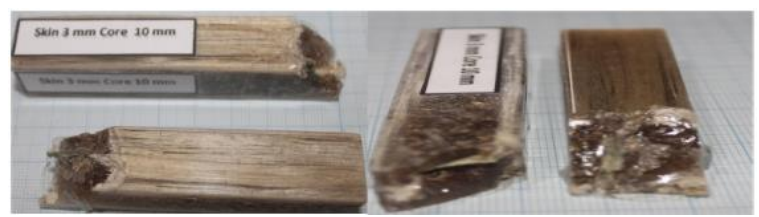

b. Sample with $3 \mathrm{~mm}$ thick skin

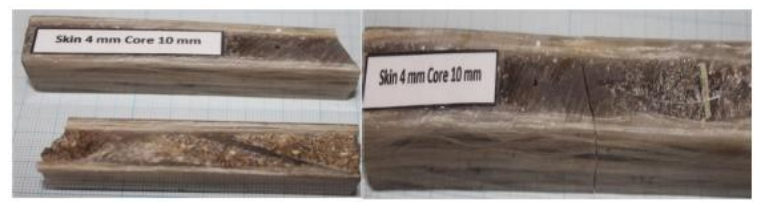

c. Sample with $4 \mathrm{~mm}$ thick skin

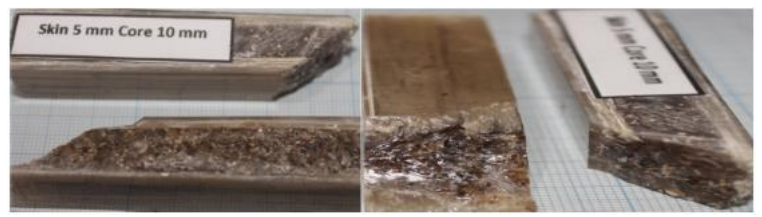

d. Sample with $5 \mathrm{~mm}$ thick skin

Figure 5 Impact strength test results

\subsection{Discussions}

The impact failure is allegedly to be caused by the shear failure of the core. Brittle specimen failure occurs on sandwich composites with thick skin of $5 \mathrm{~mm}$ and thick core sandwich composites of 5 $\mathrm{mm}$. This brittle sandwich composite has a flat cross section on both sides of the fault. The shear failure of the cores occurs in samples with $2 \mathrm{~mm}$ thick, $3 \mathrm{~mm}, 4 \mathrm{~mm}$ thick, and $10 \mathrm{~mm}$ thick core. In some samples, the shear failure of the cores is accompanied by cracks on the core so that the sandwich composite is broken in several parts.

In some impact tests, the failure does not always occur in areas directly hit by collisions. Even though, in areas hit by collisions experiencing the impact burden directly.

In testing the impact of Charpy, the failure that occurred not in the collision area because the composite manufacturing process is not possible $100 \%$ can avoid any defects. The defects can be either voids or imperfect bonds between fibers and matrices. When the load is distributed to all parts of the skin, in some parts of the defect it has a lower load-holding force than the other parts. Therefore the failures that occur are not in the collision area but in other parts of the defect.

The extent of impact damage to the sandwich structure is affected by the core material from the sandwich surface laminate stack, size, mass, pendulum speed and the ability of the sandwich component to absorb shock loads. In the sandwich structure with delamination core foam can be detected i.e. the impacted area, which is between the skin and core [10].

\section{CONCLUSIONS}

Based on the results, the characteristics of the sengon laut sawdust as a composite sandwich are:

1. The toughness of the sandwich composite impact will increase as the thickness of composite sandwich skin increases,

2. The composite sandwich with $2 \mathrm{~mm}$, the average of absorption energy and impact strength of $1,3930 \mathrm{~J}$ and $0,00663 \mathrm{~J} / \mathrm{mm}^{2}$, respectively,

3. The composite sandwich with $3 \mathrm{~mm}$, the average of absorption energy and impact strength of $2,1778 \mathrm{~J}$ and $0,00907 \mathrm{~J} / \mathrm{mm}^{2}$, respectively,

4. The composite sandwich with $4 \mathrm{~mm}$, the average of absorption energy and impact strength of $2,7860 \mathrm{~J}$ and $0,01032 \mathrm{~J} / \mathrm{mm}^{2}$, respectively,

5. The composite sandwich with $3 \mathrm{~mm}$, the average of absorption energy and impact strength of $2,7664 \mathrm{~J}$ and $0,00922 \mathrm{~J} / \mathrm{mm}^{2}$, respectively. 


\section{REFERENCES}

[1] A. S. for T. and Materials, "1998 Annual Book of ASTM Standards," 1998.

[2] R. F. Gibson, Principles of composite material mechanics. CRC press, 2016.

[3] J. B. Zhong, J. Lv, and C. Wei, "Mechanical Properties of Sisal Fibre Reinforced Urea Formaldehyde Resin Composites," Express Polym Lett, vol. 1, no. 10, pp. 681-687, 2007.

[4] E. I. Kevin, O. M. Ochanya, A. M. Olukemi, S. T. N. Bwanhot, and I. Uche, "Mechanical Properties of Urea Formaldehyde Particle Board Composite," American Journal of Chemical and Biochemical Engineering, vol. 2, no. 1, pp. 10-15, 2018.

[5] K. Mylsamy and I. Rajendran, "Agave Americana Fibre Investigation on PhysioChemical and Mechanical Properties of Raw and Alkali-Treated," J of Reinforced Plastics and Composites, vol. 29, p. 2925, 2010.

[6] K. Mylsamy and I. Rajendran, "Investigation on Physio-Chemical and Mechanical Properties of Raw and Alkali-Treated Agave Americana Fiber," Journal of Reinforced Plastics and composites, vol. 29, no. 19, pp. 2925-2935, 2010.
[7] A. Zainuri and N. H. S. N. HS, "Kekakuan Bending Eksperimen Komposit Sandwich Serat Sabut Kelapa-Matrik Polyester Dengan Core Kertas Kardus," JURNAL ILMIAH MOMENTUM, vol. 7, no. 1, 2011.

[8] K. Diharjo, S. Jamasri, and H. S. B. Rochardjo, "Tensile Properties of Unidirectional Continuous Kenaf Fiber Reinforced Polyester Composite," in International Proceeding, Kentingan Physics Forum, Sebelas Maret University, Indonesia, 2005.

[9] B. Febrianto and K. Diharjo, "Kekuatan Bending Dan Impak Komposit Hibrid Sandwich Kombinasi Serat Karung Goni Dan Serat Gelas Polyester Dengan Core Kayu Sengon Laut," Skripsi, UNS, Surakarta, 2004.

[10] M. Gaedke, J. Baaran, C. Goetting, and R. Rolfes, "Impact Behavior and Residual Strength of Sandwich Structural Elements under Static and Fatigue Loading," in 19th AIAA Applied Aerodynamics Conference, 2001, p. 1222. 